\title{
Effects of Bank Capital on Profitability and Credit Risk: The Case of Vietnam's Commercial Banks
}

\author{
NGUYEN THI HONG VINH \\ Banking University HCMC - vinhnth@ buh.edu.vn \\ LE PHAN THI DIEU THAO \\ Banking University HCMC - dieuthaodhnh@gmail.com
}

\section{ARTICLE INFO ABSTRACT}

Article history:

Received:

Nov. 27, 2015

Received in revised form:

Mar. 18, 2016

Accepted:

Sep. 23, 2016
This paper seeks to examine the effects of bank capital on profitability and credit risk of 30 Vietnam's commercial banks from 2007 to 2014. Using the system generalized method of moments (GMM), the paper conducts several tests on the moral hazard and regulatory hypotheses on the relationships among bank capital, profitability, and credit risk. With no regard to other determinants, its results indicate that the effects are evident, i.e. bank risk is found to impact differently on bank returns, and it is also negatively associated with credit risk of commercial banks in Vietnam.

Keywords:

Bank capital, credit risk, profitability, commercial banks. 


\section{Problem statement}

After the 2008 financial crisis the Basel Committee on Banking Supervision (BCBS) developed Basel III with new proposals concerning capital, leverage, and other standards on liquidity, which add in further measures on risk governance to enhance the regulation, monitoring, and management of risk in the banking industry (BIS, 2011). The newly introduced standards on capital and capital buffers demand more capital holding and higher quality capital, compared to those required in Basel II.

In addition, credit crunches emphasized an urgent need to further capture the determinants of bank risk in the event of downturns in capital adequacy (Festic et al., 2011). Not surprisingly, the relations among bank capital, profitability, and credit risk become a topical issue, particularly as capital can either increase benefits or exert adverse effect on bank profits. In Asia, Barth et al. (2008) found evidence of this kind of nexus in several Asian countries after the impact of the financial crisis: the Philippines, Singapore, and Indonesia should strengthen capital requirements, which need to be loosened in some others such as South Korea, Japan, and so on.

The equity capital of Vietnam's commercial banks is constantly increasing, reaching an average rate of increase of $3.12 \%$ in 2007-2014, and a few banks (HDB, MB, MDB) have shown a rise in equity of over $6 \%$ after merging and also in their capitalization rates. Moreover, banks' profitability and credit risk have a tendency to fluctuate during this period. So, does the equity on the increase lead to increased profitability and reduced credit risk of commercial banks? 


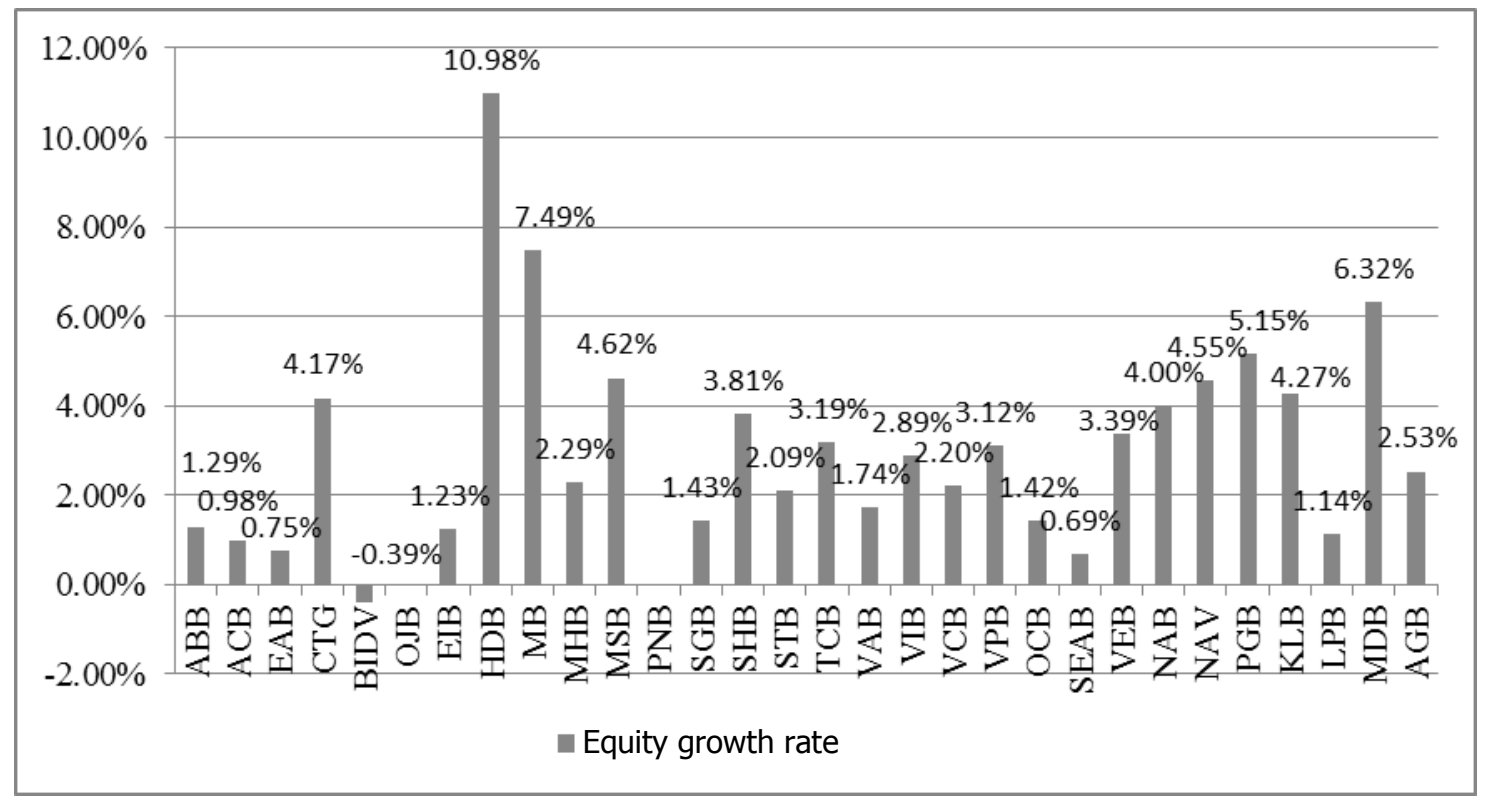

Figure 1. Percentage of increase in equity of Vietnam's commercial banks (2014 against 2007)

Source: calculated based on annual reports of the banks

In this paper the relationships among bank capital, profitability, and credit risk of Vietnam's commercial banks are examined over the 2007-2014 period, which marked the country's accession to WTO and the global financial crisis and is therefore perceived as significant to the commercial banking system. The findings from the paper will help formulate sound policies that enhance bank performance, raise profitability, and control and/or reduce risk for the sector.

\section{Literature review}

\subsection{Effect of bank capital on credit risk}

Bank capital is the bank's own funds, also known as equity capital, including owner's equity and supplementary capital (Mishkin, 2010). According Jorion (2009), credit risk is the economic loss caused by the non-performance of a financial contract as signed between the parties involved, and is measured by the cost of replacing cash flows in case of the other party's default. 
The nexus between bank capital and credit risk is established based on two kinds of hypotheses:

Moral hazard hypotheses: This theory, which was elaborated by Keeton and Morris (1987), who investigated the case of American commercial banks from 1979 though 1985, predicts that banks with rather low capital react to moral hazard incentives by raising the riskiness of loan portfolio, which causes higher average levels of nonperforming loans in later years. Their findings exhibit increased loss rates for the group of banks with comparatively low equity-to-asset ratio. Thus, bank capital is negatively related to risk. The negative association between moral hazard and capital ratios was also detected by Louzis et al. (2010). By using loan loss provision, Berger et al. (2013), who conducted an empirical study on 42 Asian banks, found that equity negatively relates to credit risk. While Jacques and Nigro (1997) concluded a negative correlation between changes in capital and risk, Agusman et al. (2008), in probing a series of Asian banks between 2008 and 2013, indicated that equity-to-asset ratio is negatively yet statistically insignificantly related to risk. According to Agoraki et al. (2011), capital is attributed to reducing risk in general, but this effect dramatically diminishes or even becomes reversed for banks with market power.

Regulatory hypotheses: In contrast with moral hazard theory, the regulatory hypothesis maintains that the management motivates banks to increase their capital in harmony with risk levels. Hence, a positive relation exists between capital and credit risk; the higher the risk, the greater the bank capital. This nexus is partly derived from supervision of market efficiency (Shrieves \& Dahl, 1992; Jacques \& Nigro, 1997).

As one of the pioneers, Pettway (1976) inspected the relationship between capital structure and credit risk of banks in the US and figured out that the ratio of equity to total assets is positively associated with risk. Also based on data collated in the same country, Shrieves and Dahl (1992) achieved the outcome of the positive relation between the two factors, and so did others, such as Rime (2001) and Iannotta et al. (2007), in their adopting European data.

\subsection{Effect of bank capital on profitability}

There have been a few studies showing that bank capital positively relates to profitability (Berger, 1995; Jacque \& Nigro, 1997; Demirgüç-Kunt \& Huizinga, 2000; Rime, 2001; Iannotta et al., 2007). Goddard et al. (2004) asserted the positive correlation 
between equity-to-asset ratio and bank returns for the case of six larged-sized European banks over the 1992-1998 period.

However, Altunbas et al. (2007) discovered the ineffective performance of banks in Europe that held additional capital sources. A negative association was exposed by Goddard et al. (2013) between capital ratio and profitability that reflects a trade-off between bank profit and risk of those in eight EU member countries during 1992-2007.

Another approach to the impact of capital on profitability is structure-conductperformance paradigm, which argues that a change in market structure or the level of bank concentration does have influence profitability. Bank profitability has been found to be significantly related to market structure. For instance, Heggestad (1977), Short (1979), and Akhavein et al. (1997) documented that in a financial system characterized by low competitiveness, large-size corporations are more efficient, and this should bring about a higher level of market concentration and profitability. Lee and Hsieh (2013) found different impacts of equity on different return variables, which were similarly confirmed by Ayaydin and Karakaya (2014), who studied the group of 23 commercial banks in Turkey during 2003-2011.

\section{Methodology}

This study applies an Arellano-Bond dynamic two-step dynamic panel data estimator while using GMM technique to handle the problems of potential endogeniety, heteroskadasticity, and data correlation (Doytch \& Uctum, 2011). The system GMM estimation allows for a more flexible variance-covariance structure of the moment conditions, whereas the GMM approach proves better than the traditional OLS estimator in testing the movement of financial variables (Driffill et al., 1998).

According to Ayaydin and Karakaya (2014), this method is suitably used for: (i) short time and a large number of individuals and/or banks involved; (ii) an existing linear functional relationship; and (iii) more specifically, in a period when economic and financial behavior is affected mostly by past experiences, old patterns of behavior, financial or economic relationships, and lagged values of the variables to be tested along with the research model.

Two different estimation techniques can be applied to a dynamic panel data model: (i) differenced panel estimation to eliminate unsuitable variables; and (ii) system panel estimation combining differenced regression with regression in levels to minimize 
potential errors and inaccuracy relating to differenced estimation (Arellano \& Bover, 1995). The GMM estimation method comprises two variations, one of which the twostep estimator is considered more efficient, especially for the system one.

We derive the following equations from Lee and Hsieh (2013), Altunbas et al. (2007), and Goodard et al. (2004), applicable to the context of Vietnam's commercial banking system. The effects of bank capital on profitability and credit risk can be clarified as follows:

$$
\begin{aligned}
& \pi_{i t}=\alpha_{0}+\alpha_{1} \pi_{i t-1}+\alpha_{2} V_{i t}+\alpha_{3} F_{i t}+\lambda_{i}+\eta_{i t} \\
& R_{i t}=\beta_{0}+\beta_{1} R_{i t-1}+\beta_{2} V_{i t}+\beta_{3} F_{i t}+\mu_{i}+v_{i t}
\end{aligned}
$$

where $t$ and $i$ denote the year $t$ and $i$ th bank respectively, $\lambda_{i}$ and $\mu_{i}$ denote the effect of bank-specific factors, and $\eta_{i t}$ and $v_{i t}$ are error terms.

Equations (1) and (2) are set to inspect the effect of bank capital on profitability and credit risk of Vietnam's commercial banks.

$V_{i t}$ is bank capital, measured by the ratio of equity to total assets; $\pi_{i t}$ is profitability of bank $i$ in year $t$, proxied by ROA (return on assets) and ROE (return on equity). In the second equation $R_{i t}$ denotes credit risk of bank $i$ in year $t$, represented by non-performing loans $\left(N P L_{i t}\right)$ and loan loss reserves $\left(L L R_{i t}\right) . F_{i t}$ is a set of explanatory variables while $\alpha_{1}$ and $\beta_{1}$ are the estimated coefficients for profitability and risk of the previous year respectively. According to Goddard et al. (2004), the significance of $\alpha_{1}$ implies that abnormal profit or risk persists over years.

The control variables include loan-to-deposit ratio and bank size (Casu \& Girardone, 2006; Short, 1979). In this research the former is expected to positively relate to both credit risk and profitability, whereas it is anticipated that the effect of the latter is negative on credit risk yet is positive on profitability.

Macro variables employed in the model are external control variables to include economic growth rate and inflation in accordance with Lee and Hsieh (2013), Altunbas et al. (2007), and Goddard et al. (2004). The growth rate is expected to relate negatively to credit risk but positively to profitability. The inflation rate, in addition, will have a positive impact on both the risk and profitability.

The Sargan test which determines the suitability of the instruments used in GMM estimation is to check the endogeneous limits of the model. It has the null hypothesis that the instruments are exogenous, i.e. they have no correlation with the error terms in 
the model. To test the problem of autocorrelation with the null hypothesis that no autocorrelation exists, Arellano-Bond test is employed for differenced residuals.

\section{Data}

The collected panel data include 232 observations of 30 commercial banks in Vietnam for the 2007-2014 period. The statistics were retrieved from annual financial statements that had been audited from these banks. The stated number of observations achieved resulted from insufficient information disclosed by some banks, whereas macro data were obtained from the IFS database. The data were applicable to 2014, yet some banks continued with their merger and acquisition until 2015 and 2016. The sample of 30 commercial banks is reported in Table 1.

\section{Table 1}

Description of the study sample

\begin{tabular}{|c|c|c|c|}
\hline Order & Notation & Full form & Note \\
\hline 1 & $\mathrm{ABB}$ & An Binh Commercial Joint Stock Bank & \\
\hline 2 & $\mathrm{ACB}$ & Asia Commercial Joint Stock Bank & \\
\hline 3 & BIDV & $\begin{array}{l}\text { Bank for Investment and Development of } \\
\text { Vietnam }\end{array}$ & \\
\hline 4 & CTG & $\begin{array}{l}\text { Vietnam Joint Stock Commercial Bank for } \\
\text { Industry and Trade }\end{array}$ & \\
\hline 5 & EAB & DongA Joint Stock Commercial Bank & \\
\hline 6 & DDB & Ocean Commercial Joint Stock Bank & $\begin{array}{l}\text { changed into Ocean } \\
\text { Commercial One Member } \\
\text { Limited Liability Bank }\end{array}$ \\
\hline 7 & EIB & $\begin{array}{l}\text { Vietnam Export Import Commercial Joint } \\
\text { Stock Bank }\end{array}$ & \\
\hline 8 & HDB & $\begin{array}{l}\text { Ho Chi Minh City Housing Development } \\
\text { Bank }\end{array}$ & \\
\hline 9 & $\mathrm{MB}$ & Military Commercial Joint Stock Bank & \\
\hline 10 & MHB & Mekong Delta Housing Development Bank & merged into BIDV in 2015 \\
\hline
\end{tabular}




\begin{tabular}{|c|c|c|c|}
\hline Order & Notation & Full form & Note \\
\hline 11 & MSB & $\begin{array}{l}\text { Vietnam Maritime Commercial Joint Stock } \\
\text { Bank }\end{array}$ & \\
\hline 12 & PNB & Southern Commercial Joint Stock Bank & $\begin{array}{l}\text { merged into Sacombank in } \\
2015\end{array}$ \\
\hline 13 & SGB & Saigon Bank for Industry and Trade & \\
\hline 14 & SHB & $\begin{array}{l}\text { Saigon-Hanoi Commercial Joint Stock } \\
\text { Bank }\end{array}$ & \\
\hline 15 & STB & $\begin{array}{l}\text { Saigon Thuong Tin Commercial Joint } \\
\text { Stock Bank }\end{array}$ & $\begin{array}{l}\text { merged into Southern Bank in } \\
2015\end{array}$ \\
\hline 16 & TCB & $\begin{array}{l}\text { Vietnam Technological and Commercial } \\
\text { Joint Stock Bank }\end{array}$ & \\
\hline 17 & VAB & $\begin{array}{l}\text { Vietnam Asia Commercial Joint Stock } \\
\text { Bank }\end{array}$ & \\
\hline 18 & VIB & $\begin{array}{l}\text { Vietnam International Commercial Joint } \\
\text { Stock Bank }\end{array}$ & \\
\hline 19 & VCB & $\begin{array}{l}\text { Joint Stock Commercial Bank for Foreign } \\
\text { Trade of Vietnam }\end{array}$ & \\
\hline 20 & VPB & $\begin{array}{l}\text { Vietnam Prosperity Joint Stock } \\
\text { Commercial Bank }\end{array}$ & \\
\hline 21 & OCB & Orient Commercial Joint Stock Bank & \\
\hline 22 & SEAB & $\begin{array}{l}\text { Southeast Asia Commercial Joint Stock } \\
\text { Bank }\end{array}$ & \\
\hline 23 & VEB & $\begin{array}{l}\text { Viet Capital Bank Commercial Joint Stock } \\
\text { Bank }\end{array}$ & \\
\hline 24 & NAB & Nam A Commercial Joint Stock Bank & \\
\hline 25 & NAV & Nam Viet Commercial Joint Stock Bank & $\begin{array}{l}\text { changed into } \\
\text { National Citizen Commercial } \\
\text { Joint Stock Bank (NCB) }\end{array}$ \\
\hline 26 & PGB & $\begin{array}{l}\text { Petrolimex Group Commercial Joint Stock } \\
\text { Bank }\end{array}$ & $\begin{array}{l}\text { merged into Vietnam Joint } \\
\text { Stock Commercial Bank for } \\
\text { Industry and Trade in } 2016\end{array}$ \\
\hline
\end{tabular}




\begin{tabular}{|c|c|c|c|c|c|c|c|}
\hline Order & \multicolumn{2}{|c|}{ Notation } & Full form & \multicolumn{4}{|c|}{ Note } \\
\hline 27 & \multicolumn{2}{|c|}{ KLB } & \multicolumn{5}{|c|}{ Kien Long Commercial Joint Stock Bank } \\
\hline 28 & \multicolumn{2}{|c|}{ LPB } & \multicolumn{5}{|c|}{$\begin{array}{l}\text { Lien Viet Post Joint Stock Commercial } \\
\text { Bank }\end{array}$} \\
\hline 29 & \multicolumn{2}{|c|}{ MDB } & \multicolumn{5}{|c|}{$\begin{array}{l}\text { Mekong Development Joint } \\
\text { Stock Commercial Bank }\end{array}$} \\
\hline 30 & \multicolumn{2}{|c|}{$\mathrm{ARB}$} & \multicolumn{5}{|c|}{$\begin{array}{l}\text { Vietnam Bank for Agriculture and Rural } \\
\text { Development }\end{array}$} \\
\hline \multirow{3}{*}{\multicolumn{8}{|c|}{$\begin{array}{l}\text { From previous studies we choose sever } \\
\text { impacting on profitability and credit risk of Vi } \\
\text { is measured by ROA and ROE, whereas non-per } \\
\text { employed to estimate banks' credit risk. Add } \\
\text { impacts on profitability and risk, including tho } \\
\text { (e.g., loan/deposit ratio), banks size, and som } \\
\text { economic growth. } \\
\text { Table } 2 \\
\text { Description of the variables used in the study }\end{array}$}} \\
\hline & & & & & & & \\
\hline & & & & & & & \\
\hline \multirow{2}{*}{ Varia } & & & \multirow{2}{*}{ Indicator } & \multirow{2}{*}{\multicolumn{2}{|c|}{ Measured by }} & $\begin{array}{r}\text { Expected } \\
\text { coeff }\end{array}$ & $\begin{array}{l}\text { rrelation } \\
\text { ient }\end{array}$ \\
\hline & & & & & & $\begin{array}{l}\text { With } \\
\text { profitablility }\end{array}$ & $\begin{array}{l}\text { With credit } \\
\text { risk }\end{array}$ \\
\hline \multicolumn{8}{|c|}{ Dependent variable } \\
\hline \multirow{2}{*}{\multicolumn{2}{|c|}{ Profitability }} & \multicolumn{2}{|c|}{$\begin{array}{l}\text { Return on } \\
\text { assets }\end{array}$} & $\begin{array}{l}\text { Profit after tax/ } \\
\text { total assets }\end{array}$ & $\mathrm{ROA}$ & & \\
\hline & & \multicolumn{2}{|c|}{$\begin{array}{l}\text { Return on } \\
\text { equity }\end{array}$} & $\begin{array}{l}\text { Profit after } \\
\text { tax/equity }\end{array}$ & ROE & & \\
\hline \multicolumn{2}{|c|}{ Credit risk } & \multicolumn{2}{|c|}{$\begin{array}{l}\text { Non- } \\
\text { performing } \\
\text { loans }\end{array}$} & $\begin{array}{l}\text { Non-performing } \\
\text { loans/total gross } \\
\text { loans }\end{array}$ & NPL & & \\
\hline
\end{tabular}




\begin{tabular}{|c|c|c|c|c|c|}
\hline \multirow{3}{*}{ Variable } & \multirow{2}{*}{ Indicator } & \multirow{2}{*}{ Measured by } & \multirow{2}{*}{ Notation } & \multicolumn{2}{|c|}{$\begin{array}{l}\text { Expected correlation } \\
\text { coefficient }\end{array}$} \\
\hline & & & & $\begin{array}{l}\text { With } \\
\text { profitablility }\end{array}$ & $\begin{array}{l}\text { With credit } \\
\text { risk }\end{array}$ \\
\hline & $\begin{array}{l}\text { Loan loss } \\
\text { reserves }\end{array}$ & $\begin{array}{l}\text { Loan loss } \\
\text { reserves/total gross } \\
\text { loans }\end{array}$ & LLR & & \\
\hline \multicolumn{6}{|c|}{ Independent variable } \\
\hline \multirow{3}{*}{$\begin{array}{l}\text { Bank control } \\
\text { variable }\end{array}$} & Equity & Equity/total assets & Equity & $(+)$ & $(-)$ \\
\hline & $\begin{array}{l}\text { Loan-to-deposit } \\
\text { ratio }\end{array}$ & Loans/deposit & LTD & $(+)$ & $(+)$ \\
\hline & Bank size & Log of total assets & Lnsize & $(+)$ & $(-)$ \\
\hline \multirow{2}{*}{$\begin{array}{l}\text { Macro } \\
\text { control } \\
\text { variable }\end{array}$} & $\begin{array}{l}\text { Economic } \\
\text { growth rate }\end{array}$ & GDP & GDP & $(+)$ & $(-)$ \\
\hline & Inflation rate & CPI & INF & $(+)$ & $(+)$ \\
\hline
\end{tabular}

The following table reports the descriptive statistics of the studied variables in percentage. ROA and ROE range rather largely $(0.01-16.75 \%$ and $0.07-44.49 \%$ respectively), which implies a wide difference in bank performance. Additionally, the average rate of non-performing loans between 2007 and 2014 is 2.25\%, compared to total loans with the highest and lowest NPL rates of $8.827 \%$ and $0.067 \%$ as recorded from Saigon-Hanoi Commercial Joint Stock Bank in 2012 and Ocean Commercial Joint Stock Bank in 2007, respectively.

Capital as measured by equity/total assets reaches $11.965 \%$ on average, and the highest rate of $61.408 \%$ and the lowest rate of $2.905 \%$ are revealed by Mekong Development Joint Stock Commercial Bank and Mekong Delta Housing Development Bank in 2013 and 2008 respectively. Also in the research period loan-to-deposit ratios are commonly high with the average level of $64.422 \%$, suggesting that Vietnam's commercial banks still depend heavily on their credit activities. 


\section{Table 3}

Statistical results of the variables calculated for commercial banks in the sample (2007-2014)

\begin{tabular}{lccccc}
\hline Variable & Obs. & Mean & Std. dev. & Min & Max \\
\hline ROA & 232 & 1.499 & 1.916 & 0.010 & 16.750 \\
ROE & 232 & 11.525 & 7.512 & 0.070 & 44.490 \\
NPL & 232 & 2.250 & 1.324 & 0.062 & 8.827 \\
EQUITY & 232 & 11.965 & 8.329 & 2.905 & 61.408 \\
LLR & 232 & 1.288 & 0.689 & 0.128 & 3.885 \\
LTD & 232 & 64.422 & 23.735 & 20.047 & 160.488 \\
LNSIZE & 232 & 17.702 & 1.301 & 14.270 & 20.362 \\
GDP & 232 & 5.934 & 0.604 & 5.25 & 7.13 \\
INF & 232 & 10.852 & 6.128 & 4.086 & 23.116 \\
\hline
\end{tabular}

Source: calculated based on annual reports of the banks and IFS for the 2007-2014 period

\section{Empirical results}

The fluctuation trends of dependent and independent variables are presented in Figures 2-5. Figure 2 plots the positive values of both ROA and ROE, which have a decreasing tendency from 2007 to 2014. The collected data also reveal the average values of ROA and ROE of $0.690 \%$ and $7.230 \%$ respectively, and those in 2014 are $2.46 \%$ and $16.15 \%$, down compared to those in 2007 . 


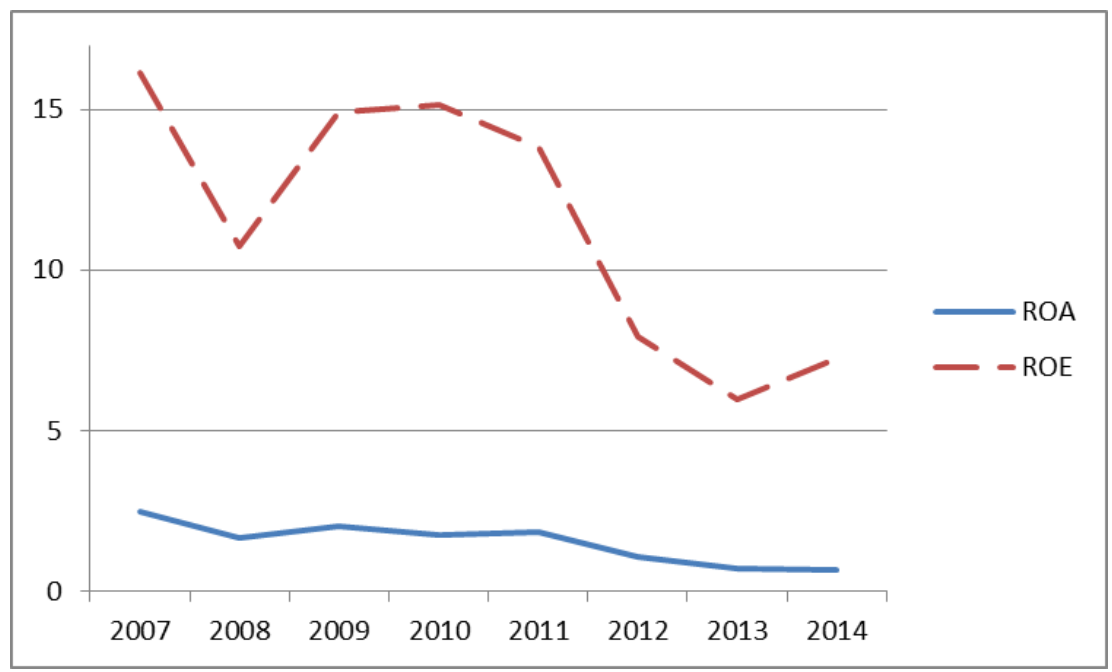

Figure 2. Profitability

Source: calculated based on annual reports of the banks and IFS for the 2007-2014 period

Figure 3 illustrates the trends of non-performing loans and loan loss reserves of Vietnam's commercial banks, which are quite similar and both on the increase in the research period. Overall, non-performing loans reflect the highest increase in 2012 with the average rate of increase of $3.5 \%$, whereas this figure for loan loss reserves is $1.8 \%$ in the same year.

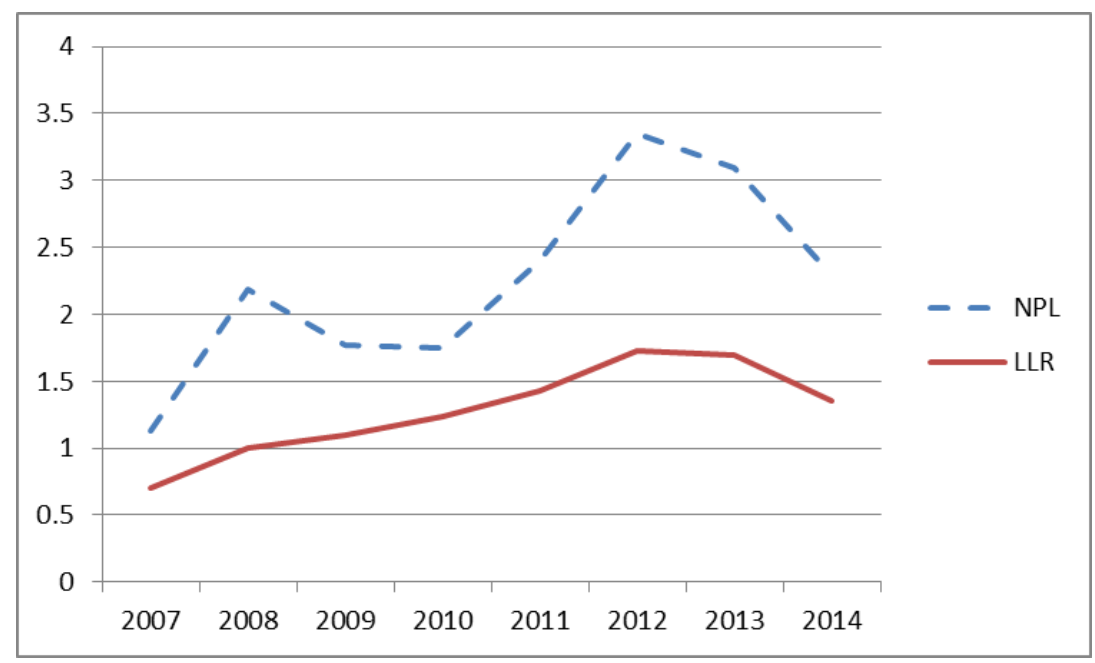

Figure 3. Credit risk

Source: calculated based on annual reports of the banks and IFS for the 2007-2014 period 
In Figure 4 the avarage value of the equity-to-asset ratio which represents capital adequacy reaches $11.965 \%$, and its highest value $(15.02 \%)$ is recorded in 2008. The values of loan-to-deposit ratio range between $57.13 \%$ and $80.47 \%$ and tend to decrease in 2014. On the contrary, those of bank size are on the increase in the whole period.

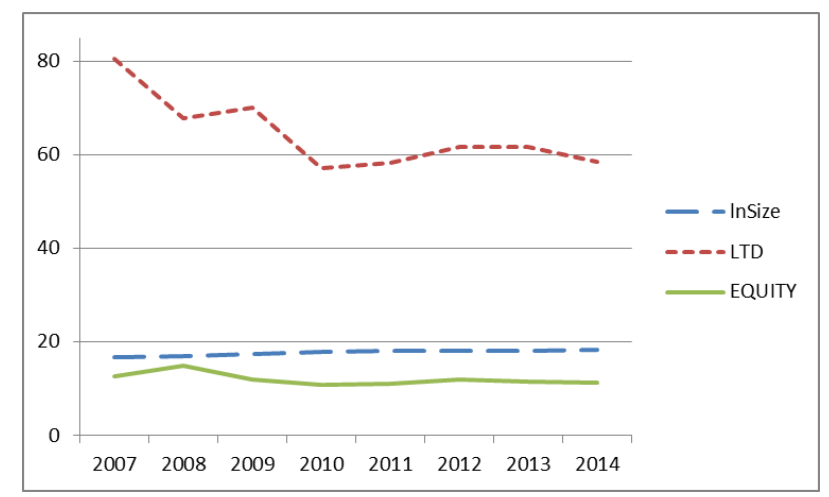

Figure 4. Bank-specific factors

Source: calculated based on annual reports of the banks and IFS for the 2007-2014 period

Figure 5 shows economic growth rate (real GDP) and inflation rate of Vietnam. While the former ranges from 5\% to 7\%, the fluctuation range of the latter is greater (4$23.11 \%$ ). This results from the growing instability of the national and global economy.

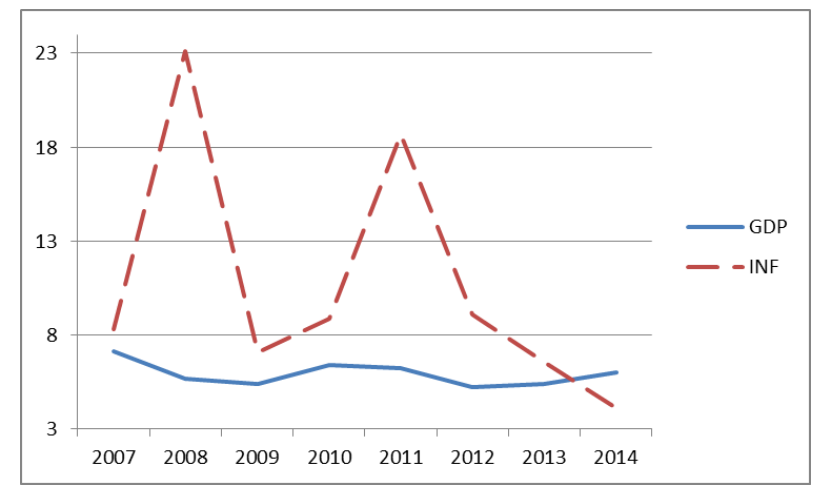

Figure 5. Macro factors

Source: calculated based on annual reports of the banks and IFS for the 2007-2014 period 
Table 4 shows the regression results of the impact of bank capital on profitability. The Sargan testing results suggest no existence of endogeneity; thus, the null hypothesis is accepted (the variables are exogenous). From the result of $\operatorname{AR}(2)$ test, it can be concluded that there exists no autocorrelation.

\section{Table 4}

Estimated results of the effect of capital on profitability of Vietnam's commercial banks

\begin{tabular}{|c|c|c|c|c|}
\hline \multirow{2}{*}{ Variable } & \multicolumn{2}{|c|}{ ROA } & \multicolumn{2}{|c|}{ ROE } \\
\hline & Coef. & SE & Coef. & SE \\
\hline $\mathrm{ROA}_{\mathrm{it}-1}$ & $0.461 * * *$ & 0.0542 & & \\
\hline $\mathrm{ROE}_{\mathrm{it}-1}$ & & & $0.632 * * *$ & 0.1874 \\
\hline EQUITY & $0.093 * *$ & 0.0421 & $-0.497 * *$ & 0.3989 \\
\hline LTD & $0.018^{*}$ & 0.0063 & $-0.222 * * *$ & 0.0543 \\
\hline Lnsize & -0.035 & 0.1275 & 0.683 & 0.0654 \\
\hline GDP & $0.165 * *$ & 0.1814 & $0.680 * *$ & 0.5874 \\
\hline INF & $0.017 * * *$ & 0.0197 & 0.154 & 0.1377 \\
\hline No. of observations & \multicolumn{2}{|c|}{202} & \multicolumn{2}{|c|}{202} \\
\hline No. of banks & \multicolumn{2}{|c|}{30} & \multicolumn{2}{|c|}{30} \\
\hline No. of instruments & \multicolumn{2}{|c|}{12} & \multicolumn{2}{|c|}{15} \\
\hline Sargan test & \multicolumn{2}{|c|}{0.432} & \multicolumn{2}{|c|}{0.545} \\
\hline Serial correlation test & \multicolumn{2}{|c|}{0.291} & \multicolumn{2}{|c|}{0.156} \\
\hline
\end{tabular}

Note: $* * *, * *$, and $*$ denote significance levels of $1 \%, 5 \%$, and $10 \%$ respectively.

Source: calculated using Stata 11

The results in Table 4 indicate the same direction and significance of the lagged values of dependent variables, which implies that profit earned in the previous term is critical to current bank profitability. The effects of independent variables on profitability, overally, are statistically significant.

Different results are achieved from the effect of equity-to-asset ratio on profitability based on different variables (ROA and ROE) denoting bank's return. This is logical due 
to the fact that the ratio is positively associated with ROA, yet is negatively related to ROE (higher equity leads to higher profit). Moreover, the higher equity-to-asset ratio causes reduced equity risk and thus reduced ROE. This result is consistent with Berger (1995), Demirgüç- Kunt and Huizinga (2000), Iannotta et al. (2007), Naceur and Omran (2011), Berger and Bouwman (2013), and Lee and Hsieh (2013).

Concerning the control variables, the effects of loan-to-deposit ratio are positive and negative on ROA and ROE respectively, whereas those of bank size are negative and positive and are all significant. In the surveyed period, there is a reduction in the loanto-deposit ratio of Vietnam's commercial banks from 2008 in addition to reduced bank profit. Since the earnings of Vietnam's commercial banking institutions primarily come from income from credit actitivites, a fall in loans is conducive to diminishing profit.

In addition, economic growth rate and inflation rate both have positive effects on ROA and ROE, but the nexus between inflation and ROE is not statistically significant. The lower the growth rate, the more substantially the profit reduces, which can be answered by the fact that during deceleration in economic growth the operating performance of businesses appears less effective, thus affecting banks' repayment capacity and leading up to reduced profit. Low inflation, which entails diminishing lending rates, is conducive to decrease in bank earnings in the researched phase.

\section{Table 5}

Estimated results of the effect of capital on credit risk of Vietnam's commercial banks

\begin{tabular}{lcccc}
\hline \multirow{2}{*}{ Variable } & \multicolumn{2}{c}{ NPL } & \multicolumn{2}{c}{ LLR } \\
\cline { 2 - 5 } & Coef. & SE & Coef. & SE \\
\hline NPL it-1 $_{\text {LLR }}$ it-1 & $0.691^{* * * *}$ & 0.0521 & & \\
EQUITY & & & $0.475^{* * *}$ & 0.0811 \\
Lnsize & $-0.053^{* * *}$ & 0.0129 & $-0.225^{*}$ & 0.0163 \\
LTD & $0.048^{*}$ & 0.0265 & $0.387 * * *$ & 0.0486 \\
GDP & $-0.565^{* *}$ & 0.0128 & -0.232 & 0.0023 \\
INF & $-0.086^{* * *}$ & 0.0432 & $-0.054^{* *}$ & 0.0388 \\
No. of observations & $0.019^{* * *}$ & 0.0022 & 0.017 & 0.0023 \\
& & 202 & & 202
\end{tabular}




\begin{tabular}{|c|c|c|c|c|}
\hline \multirow{2}{*}{ Variable } & \multicolumn{2}{|c|}{ NPL } & \multicolumn{2}{|r|}{ LLR } \\
\hline & Coef. & SE & Coef. & SE \\
\hline No. of banks & \multicolumn{2}{|c|}{30} & \multicolumn{2}{|r|}{30} \\
\hline No. of instruments & \multicolumn{2}{|c|}{14} & \multicolumn{2}{|r|}{14} \\
\hline Sargan test & \multicolumn{2}{|c|}{0.353} & \multicolumn{2}{|r|}{0.548} \\
\hline Serial correlation test & \multicolumn{2}{|c|}{0.169} & \multicolumn{2}{|r|}{0.382} \\
\hline
\end{tabular}

Note: $* * *, * *$, and $*$ denote significance levels of $1 \%, 5 \%$, and $10 \%$ respectively.

Source: calculated using Stata 11

The results of the effect of bank capital on credit risk are demonstrated in Table 5, which also suggests that the impact of independent variables on profitability is statistically significant. Similarly, the Sargan and AR(2) testing results show neither endogeneity (the null hypothesis is accepted that the variables are exogenous) nor autocorrelation.

Table 5 also indicates that the coefficient of $\mathrm{NPL}_{\mathrm{it}-1}$ of 0.691 carries similar sign to that of NPL and the coefficient of $L_{L} R_{\mathrm{it}-1}$ of 0.475 takes the same sign as that of LLR at $1 \%$ level. This implies that banks' credit risk of the previous year is significant to that of the current year, which is in line with the findings of Salas and Saurina (2002).

A negative association is revealed between bank capital and NPL and LLR at 1\% level. Consistent with the moral hazard theory of Keeton and Morris (1987), this argues that banks with low capitalization have to cope with loan portfolio risk (due to lack of diversification of loans and focus on a certain few of target customers) and higher nonperforming loan rates. Contrarily, higher capitalization enables banks to diversify their loan portfolios and thus have lower chance of taking credit risk.

The variable loan-to-deposit ratio exhibits a negative relation to non-performing loans, which is opposite to bank size that relates positively to non-performing loans. As can be explained, when large banks take on excessive risk by increasing their use of loans, more non-performing loans will be suffered. In Vietnam larger bank size is often synonymous with more branches and subsidiaries; poor management practices and improper control of non-performing loans, nevertheless, have caused them to rise. Furthermore, large-sized banks, such as Vietcombank, BIDV, Vietinbank, and Agribank, offer borrowings to state-owned enterprises with high outstanding loans 
(accouting for 67\% of total outstanding loans of the banking system in 2011), whereas these firms show less efficiency and loan evaluation process is not strictly controlled, which is thus bringing about higher rates of problem loans.

Also shown in Table 5 are the negative (positive) impacts of growth (inflation) rate on non-performing loans at $1 \%$ level with the use of system GMM estimator. These results are compatible with those of Fofact (2005). In case of high inflation rates, tightened fiscal and monetary policies are employed to impose difficulties on borrowers. This, as a result, leads to lower repayment capacity and thus higher problem loans among commercial banks. In the surveyed country the average inflation rate between 2007 and 2014 is $11.67 \%$ alongside the highest rate of increase of $23.11 \%$ in 2008 . The fact itself has been conducive to a rise in non-performing loans as suffered by the Vietnam's commercial banking system.

\section{Conclusion and recommendations}

Using a panel dataset the paper aims to examine the effects of bank capital on profitability and credit risk of 30 Vietnamese commercial banks during 2007-2014. It also resolves the issue of whether the relations among equity, profitability, and credit risk of these banks underpin moral hazard or regulatory hypotheses. In light of ArellanoBover system GMM estimation results for the panel data, increasing bank capital is indicated to enhance profitability and reduce credit risk of commercial banks. The results are consistent with the moral hazard theory and findings of earlier empirical studies.

As an implication, since different return variables result in different capital-related outcomes, a single one ofted for by bank managers may be highly conducive to misleadingly adopted policies.

Due to the fact that the profitability and credit risk of Vietnam's commercial banking system are sensitive to bank capital, consideration can be given to its effects to increase profitability and control non-performing loans with respect to the following options.

For bank managers, because of the positive and negative impacts of equity on profitability and credit risk respectively, equity increases will boost profitability and lower non-performing loan rates. In raising equity, banks should formulate logical policies on financial outcome distribution between dividend payout and retained earnings appropriate to be added to their equity, which may be used for re-investments and reduces the financial burden born by shareholders. 
In banking activities it is necesasry to accentuate equity management practices and search for efficient ways to evaluate risk capital and assets for precise and logical capital planning or accurate assessment of ICOR. Additionally, bank managers need to set an attainable level of credit growth, diversify loan porfolios, and restructure the loan term in order to reduce NPL rates.

Moreover, the research results reveal that the current profitability and credit risk are influenced by the previous ones; thus, sound existing risk management can reduce bad debts and increase profits in the future.

The State Bank should advice commercial banks on regulations on banking operations, especially on capital requirements. Vietnam's commercial banks are now fulfilling these in accordance with Basel 2, yet prompt compliance with Basel 3 standards is suggested to help with effective risk prevention. Since low capitalization is associated with high credit risk, increased capital should be allowed among commercial banking institutions through mergers and acquisitions.

The State Bank should also monitor debt restructuring, debt classification, and loan loss provisions of commercial banks according to the regulations defined in Circular No. 02/2013/TT-NHNN dated January 21, 2013. To set a basis for the healthy development of Vietnam's commercial banking system, the State Bank needs to establish control over credit growth and implement fiscal/monetary policies toward mid- and long-term stability.

In this study we do not classify loans by ownership types or industry, and our dataset does not cover joint-venture banks and branches of foreign banks in Vietnam due to insufficient data. Also, the variables used in the study do not clearly reflect the factors affecting the profitability and credit risk of Vietnam's commercial banks. Therefore, loan classification according to ownership types and other factors involving bank profitability and risk can be addressed in the future research

\section{References}

Agoraki, M., Delis, M. D., \& Pasiouras, F. (2011). Regulations, competition, and bank risk-taking in transition countries. Journal of Financial Stability, 7(1), 38-48.

Agusman, A., Monroe, G. S., Gasbarro, D., \& Zumwalt, J. K. (2008). Accounting and capital market measures of risk: Evidence from Asian banks during 1998-2003. Journal of Banking and Finance, $32(4), 480-488$. 
Akhavein, J. D., Swamy, P. V., \& Taubman, S. B. (1997). A general method of deriving the efficiencies of banks from a profit function. Journal of Productivity Analysis, 8(1), 71-93.

Altunbas, Y. S., Carbo, E., Gardener, P. M., \& Molyneux, P. (2007). Examining the relationships between capital, risk, and efficiency in European banking. European Financial Management, 13(1), 49-70.

Arellano, M., \& Bond, S. (1991). Some tests of specification for panel: Monte Carlo evidence and an application to employment equations. Review of Economic Studies, 58, 277-297.

Arellano, M., \& Bover, O. (1995). Another look at the instrumental-variable estimation of errorcomponents. Journal of Econometrics, 68(1), 29-52.

Ayaydin, H., \& Karakaya, A. (2014). The effect of bank capital on profitability and risk in Turkish banking. International Journal of Business and Social Science, 5(1), 252-271.

Barth, J., Caprio, G., \& Levine, R. (2008). Bank regulations are changing: For better or worse? Comparative Economic Studies, 50(4), 537-563.

Berger, A. N. (1995). The relationship between capital and earnings in banking. Journal of Money, Credit and Banking, 27(2), 432-456.

Berger, A. N., \& DeYoung, R. (1997). Problem loans and cost efficiency in commercial banks. Journal of Banking and Finance, 21(6), 849-870.

Berger, A. N., \& Bouwman, C. H. S. (2013). How does capital affect bank performance during financial crises? Journal of Financial Economics, 109, 146-176.

BIS. (2011). Core principles for effective banking supervision. Retrieved from http://www.bis.org/ list/bcbs/tid_25/index.htm

Blundell, R., \& Bond, S. (1998). Initial conditions and moment restrictions in dynamic panel data models. Journal of Econometrics, 87, 115-143.

Blundell, R., \& Bond, S. (2000). GMM estimation with persistent panel data: An application to production functions. Econometric Reviews, 19(3), 321-340.

Casu, B., \& Girardone, C. (2006). Bank competition, concentration, and efficiency in the single European market. The Manchester School, 74(4), 441-468.

Demirgüç-Kunt, A., \& Huizinga, H. (2000). Financial structure and bank profitability. World Bank Policy Research Working Paper No. 2430. Washington, DC: The World Bank.

Doytch, N., \& Uctum, M. (2011). Does the worldwide shift of FDI from manufacturing to services accelerate economic growth? A GMM estimation study. Journal of International Money and Finance, 30(3), 410-427.

Driffill, J., Psaradakis, Z., \& Sola, M. (1998). Testing the expectations hypothesis of the term structure using instrumental variables. International Journal of Finance and Economics, 3(4), 321-325.

Festic, M., Kavkler, A., \& Repina, S. (2011). The macroeconomic sources of systemic risk in the banking sectors of five new EU member states. Journal of Banking and Finance, 35(2), 310-322. 
Fofack, H. (2005). Non-performing loans in Sub-Saharan Africa: Causal analysis and macroeconomic implications. World Bank Policy Research Working Paper No. 3769. Washington, DC: The World Bank.

Goddard, J., Molyneux, P., \& Wilson, J. O. S. (2004). The profitability of European banks: A crosssectional and dynamic panel analysis. Manchester School, 72(3), 363-381.

Goddard, J., Molyneux, P., Wilson, J. O. S., \& Liu, H. (2013). Do bank profits converge? European Financial Management, 19(2), 345-365. doi: 10.1111/j.1468-036X.2010.00578.x

Heggestad, A. A. (1977). The competitive condition of US banking markets and the impact of structural reform. Journal of Finance, 32(4), 649-661.

Iannotta, G., Nocera, G., \& Sironi, A. (2007). Ownership structure, risk, and performance in the European banking industry. Journal of Banking and Finance, 31(7), 2127-2149.

Jacques, K., \& Nigro, P. (1997). Risk-based capital, portfolio risk, and bank capital: A simultaneous equations approach. Journal of Economics and Business, 49(6), 533-547.

Jorion, P. (2009). Financial risk manager handbook. NY: John Wiley \& Sons.

Keeton, R., \& Morris, S. (1987). Why do banks' loan losses differ? Federal Reserve Bank of Kansas City Economic Review, 72(5), 3-21.

Lee, C. C., \& Hsieh, M. F. (2013). The impact of bank capital on profitability and risk in Asian Banking. Journal of International Money and Finance, 32, 251-281.

Louzis, D., Vouldis, A., \& Metaxas, V. (2010). Macroeconomic and bank-specific determinants of non-performing loans in Greece: A comparative study of mortgage, business, and consumer loan portfolios. Bank of Greece Working Paper No. 118. Athens, Greece: Bank of Greece.

Mishkin, F. (2010). The economics of money banking, and financial markets. NY: Pearson.

Naceur, S. B., \& Omran, M. (2011). The effects of bank regulations, competition, and financial reforms on banks' performance. Emerging Markets Review, 12(1), 1-20.

Pettway, R. H. (1976). Market tests of capital adequacy of large commercial banks. Journal of Finance, 31(3), 865-875.

Rime, B. (2001). Capital requirements and bank behavior: Empirical evidence for Switzerland. Journal of Banking and Finance, 25(4), 789-805.

Salas, V., \& Saurina, J. (2002). Credit risk in two institutional regimes: Spanish commercial and savings banks. Journal of Financial Services Research, 22(3), 203-224.

Shrieves, R. E., \& Dahl, D. (1992). The relationship between risk and capital in commercial banks. Journal of Banking and Finance, 16(2), 439-457.

Short, B. (1979). The relation between commercial bank profit rates and banking concentration in Canada, Western Europe, and Japan. Journal of Banking and Finance, 3(4), 209-219. 